\title{
Effect of Use Perception and Easy Perception of the Use of WhatsApp Communication Media on Performance of Expertise of Members of the DPR RI Golkar Faction in 2019
}

\author{
Ricky Megantara Ibnu Sagi ${ }^{1}$ Poppy Ruliana $^{2}$ Irwansyah $^{3}$ \\ ${ }^{1}$ Postgraduate Program Student, Magister Communication Study, InterStudi College of \\ Communication, Jakarta, Indonesia \\ ${ }^{2}$ Postgraduate Study Program, Magiater Communication Studies, InterStudi College of \\ Communication, Jakarta, Indonesia \\ ${ }^{3}$ Department of Communication. FISIP. University of Indonesia, Depok, 166424 \\ Correspondence Author's Email: ricky_megantara@yahoo.com
}

\begin{abstract}
The purpose of this study is to determine and analyze the perception of Whatsapp communication media usage on the performance of the Experts. The theory used in this study is the Technology Acceptance Model theory from Davis and the performance of Mangkunegara. The research approach used is quantitative descriptive which describes, explains and translates data and results of research analyzes in written, systematic and structured. The research method used is correlation analysis and ordinal logistic regression to see the correlation between values and the effect of perception variables on the ease of use of communication media, perceived usefulness of communication media on the performance variables of experts from members of the Golkar Faction of the Republic of Indonesia. While the population in this study were all Golkar Faction Experts who were active in 2019 with a total of 455 TAA (91 DPR Members). The sampling technique used in this study is the probability of stratified random sampling. To determine the sample size using the Taro Yamane formula to obtain a sample of 213 people as respondents, data collection was done through questionnaires, interviews and documentation as well as internet studies. Data analysis uses ordinal logistic regression analysis techniques. to find out the correlative level of the dependent variable on the independent variable. The results showed that the effect of perception of usage and perceived ease of use of WhatsApp communication media was significant to the performance of Experts of the Members of the Republic of Indonesia DPR GOLKAR Faction in 2019
\end{abstract}

Keywords: perception, communication media, WhatsApp, performance

\section{INTRODUCTION}

The House of Representatives as a representative institution that accommodates and accommodates the aspirations of the people has a very strategic task and function because it has three functions namely legislation, budgeting and 
supervision. To support these tasks and functions, a support system is needed that will provide authenticity, technical and administrative support. Three supports have been made by the DPR RI Secretariat General, but because of the burden and volume of the work of the DPR as an institution as well as every DPR Member has increased. In an effort to fulfill the duties and obligations of the Indonesian Parliament, in accordance with Law No. 27 of 2009 concerning the MPR, DPR, DPD and DPRD, they can then recruit groups of Experts / Experts who are tasked with providing expertise support to the DPR in an effort to improve performance. Experts according to Law No. 27 of 2009 has the task to provide expertise or substantial support to Members of the Board, the Completeness Equipment of the DPR, and the factions in the DPR in carrying out its duties and functions.

Details of tasks related to expertise support by experts in accordance with the mandate of Law 27 of 2009 include: (1) Processing and examining issues in the field of legislation, budgeting and supervision that are delivered orally or in writing both assignments and requests from Members, Equipment and factions in forms of information and data or analysis; (2) Providing input and consideration related to problems that have received the attention of the DPR, whether requested or not; (3) Providing assistance to Members, Completeness and Faction in the DPR, in preparing materials for meetings, work visits, absorption of aspirations, and others; and (4) Developing and following developments in strategic issues that can affect the performance of the DPR RI.

Experts in the DPR are divided into 4, namely: Member Experts (TAA), Commission Experts, Faction Experts, and Agency Experts (Board Complementary Tools in addition to Commissions such as the Budget Agency, BKSAP, and others). the perceived benefits used. The same thing with aspects of employee satisfaction in the use of whatsapp communication media in the work environment will affect the communication process so that it impacts on work results. Likewise, previous research conducted by Arifin (2015) that Whatsapp facilitates them in communication activities and can also influence student behavior to be closed. Closed behavior is an attitude that will affect relationships between individuals, in this case the impact of employees who use the media. Sukrillah (2017) the role of whatsapp is able to bridge interrupted and slow information by maximizing existing groups and developing information-based hospitality. In modern organizations, the need for fast, effective and efficient communication media is one of the important factors for increasing organizational productivity and performance. The benefits of appropriate communication media to be able to support and facilitate the completion of organizational tasks effectively and efficiently. In other words, communication media is very influential on organizational performance.

The focus of this research is the extent of the influence of perception and use of WhatsApp communication media as a means of interacting, sharing 
The House of Representatives as a representative institution that accommodates and accommodates the aspirations of the people has a very strategic task and function because it has three functions namely legislation, budgeting and supervision. To support these tasks and functions, a support system is needed that will provide authenticity, technical and administrative support. Three supports have been made by the DPR RI Secretariat General, but because of the burden and volume of the work of the DPR as an institution as well as every DPR Member has increased. In an effort to fulfill the duties and obligations of the Indonesian Parliament, in accordance with Law No. 27 of 2009 concerning the MPR, DPR, DPD and DPRD, they can then recruit groups of Experts / Experts who are tasked with providing expertise support to the DPR in an effort to improve performance. Experts according to Law No. 27 of 2009 has the task to provide expertise or substantial support to Members of the Board, the Completeness Equipment of the DPR, and the factions in the DPR in carrying out its duties and functions.

Details of tasks related to expertise support by experts in accordance with the mandate of Law 27 of 2009 include: (1) Processing and examining issues in the field of legislation, budgeting and supervision that are delivered orally or in writing both assignments and requests from Members, Equipment and factions in forms of information and data or analysis; (2) Providing input and consideration related to problems that have received the attention of the DPR, whether requested or not; (3) Providing assistance to Members, Completeness and Faction in the DPR, in preparing materials for meetings, work visits, absorption of aspirations, and others; and (4) Developing and following developments in strategic issues that can affect the performance of the DPR RI.

Experts in the DPR are divided into 4, namely: Member Experts (TAA), Commission Experts, Faction Experts, and Agency Experts (Board Complementary Tools in addition to Commissions such as the Budget Agency, BKSAP, and others). the perceived benefits used. The same thing with aspects of employee satisfaction in the use of whatsapp communication media in the work environment will affect the communication process so that it impacts on work results. Likewise, previous research conducted by Arifin (2015) that Whatsapp facilitates them in communication activities and can also influence student behavior to be closed. Closed behavior is an attitude that will affect relationships between individuals, in this case the impact of employees who use the media. Sukrillah (2017) the role of whatsapp is able to bridge interrupted and slow information by maximizing existing groups and developing information-based hospitality. In modern organizations, the need for fast, effective and efficient communication media is one of the important factors for increasing organizational productivity and performance. The benefits of appropriate communication media to be able to support and facilitate the completion of organizational tasks effectively and efficiently. In other words, communication media is very influential on organizational performance. 
The focus of this research is the extent of the influence of perception and use of WhatsApp communication media as a means of interacting, sharing information, which supports its performance in carrying out its duties and functions as an expert member of the Republican Golkar Faction from Indonesia.

\section{LITERATURE REVIEW}

\section{Communication media}

Jankowski (2002), illustrates that in the modern era there is a significant and massive development of the role and function of the media. The presence of the internet has transformed communication media into new media where communication channels are decentralized; distribution of messages via satellite increases the use of cable and computer networks; audience involvement in the communication process increases; the existence of interactive communication and also the increased level of flexibility to determine the form and content through digital messages. The use of digital-based communication media (digital multimedia) in its development is not always acceptable to the public. The Concept of Technology Acceptance Model by Davis (1989) illustrates that the use of digital age communication media is determined by two main factors relating to the ease of use of communication media, as well as the perceived usefulness of the use of communication media; information, which supports its performance in carrying out its duties and functions as an expert member of the Republican Golkar Faction. from Indonesia.

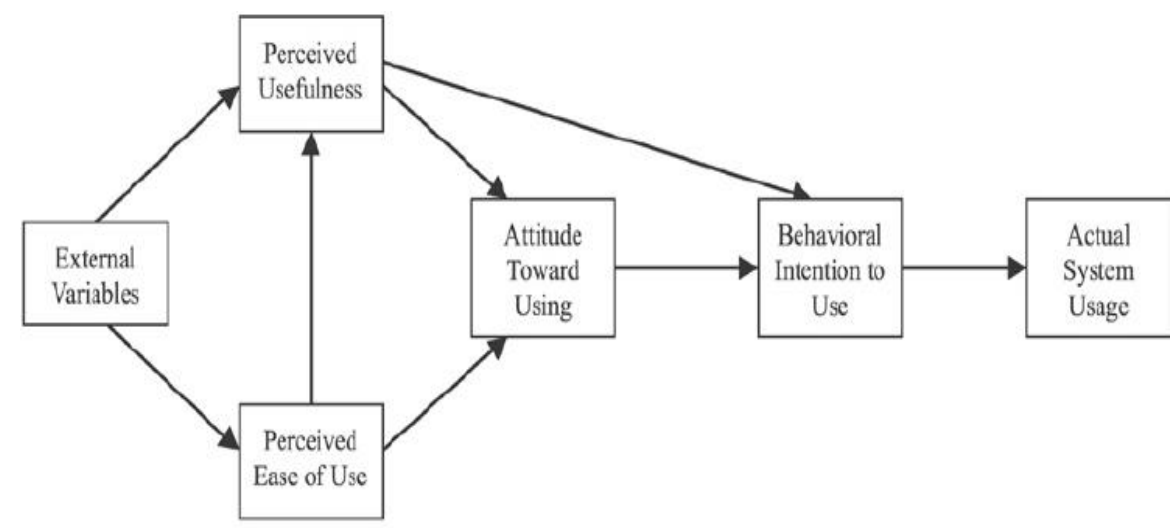

Source: Davis et al. (1989, p. 985)

Davis's Technology Acceptance Model has been widely used in determining the level of individual acceptance when dealing with technology, especially in the field of information systems (Alharbi \& Drew, 2014; Mojtahed et al., 2011), the education sector (Alharbi \& Drew, 2014), cellular trading ( Lee, Tao, $\&$ Chang, 2015) but in the field of human resources is still quite limited. Basically, 
TAM is based on social psychological theory, specifically the theory of reason action (Ajzen \& Fishein, 1980) where the acceptance of technology is determined by the reflection and reasoning of users which will influence their internal behavior, actions, intentions, and beliefs. Three factors comprise the model: Perceived benefits, ease of use and behavioral intentions in using technology are used to measure the level of user acceptance in dealing with technology. The perceived usefulness is defined as where someone believes that using a particular system will improve the performance of his work. Conversely, the perception of ease of use is when someone believes that using a particular system, will be free of effort. In addition, behavioral intention is defined as the actual use of a particular information technology system that is given and therefore technology acceptance is determined (Alharbi \& Drew, 2014). Therefore, this model is very useful in determining the level of acceptance in accepting technology in our daily activities.

\section{Usability perception}

According to Davis (1989) the perception of usability is the level at which it influences the user's attitude in using technology. If he feels that the technology or system is beneficial for its use, then the level of acceptance of that particular technology or system is very high. If not, he will refuse to use the technology system or will face techno-stress (Joo, Lim, \& Kim, 2016; Yao \& Cao, 2017). A study conducted by Lee et al. (2015) has proven that the perceived benefits positively influence customer satisfaction in using the App lifeinsurer service. When customers feel that the benefits of using the application are valuable to them, they will resist the resistance to use it. Thus, this factor will influence the customer's attitude to continue to use the application freely. On the other hand, if the perception of usability is negative, customers will give up using the application and will turn around or try to find another application that is more user friendly to use and this will cause insurance companies to attract their customers

\section{Perception of Ease of Use}

As defined by Davis (1989) the perception of ease of use is when users face difficulties in using technology because of complicated features or too many steps involved, they may refuse to use the system. For example, research conducted by Salman et al. (2014) states that ease of use can influence the attitude of support staff both directly and indirectly towards the use of technology. In other words, ease of use determines employee expectations of technology. Other research conducted by Bugembe (2010) which states that the technology acceptance model can identify why users accept or reject information technology and how user acceptance is influenced by the system. Employees hope that technology can be user friendly and easy to use to help them do their jobs better. 


\section{Behavioral intention}

According to TAM (Davis, 1989) behavioral intention is the actual act of using technology that shows that an individual accepts it. This means that when someone feels that the technology they want to use shows the benefits and features available are easy to use, the feeling of wanting to use technology or a system is very high. For example research conducted by Alharbi and Drew (2014) confirms that behavioral intentions are positively related to the use of Learning Management Systems (LMS) among teaching staff at Saqra University in Saudi Arabia. The findings of this study are also parallel with research conducted by Bugembe (2010) where if employees have a positive attitude using technology, the actual use of technology will be easy

\section{TAM and Employee Performance}

At present, mobile applications have been used extensively in the business world in promoting employee productivity and job performance. With the technology integrated with mobile devices such as smartphones, tablets, workers are willing to use technology that can help them to do their jobs better. For example such research conducted by Newman et al. (2018) around 54\% of Malaysians use WhatsApp in reading news and for communication purposes compared to $12 \%$ of those who use Facebook by $64 \%$. Newman et al's results can be seen in the table below:

\begin{tabular}{|lllll|}
\hline Rank & & Brand & For news & All \\
\hline$f$ & 1 & Facebook & $64 \%(+6)$ & $82 \%$ \\
\hline 0 & 2 & WhatsApp & $54 \%(+3)$ & $82 \%$ \\
\hline itit & 3 & YouTube & $33 \%(+7)$ & $72 \%$ \\
\hline 0 & 4 & Instagram & $17 \%(+4)$ & $45 \%$ \\
\hline P & 5 & Twitter & $13 \%(+3)$ & $25 \%$ \\
\hline$P$ & 6 & Facebook Messenger & $12 \%(+1)$ & $36 \%$ \\
\hline
\end{tabular}

Source: Top Social Media and Messaging Platforms (Source: Newman Et.Al, 2018,)

Besides being easy to use and easy to use WhatsApp features, employees feel WhatsApp helps them to do their work much faster in getting feedback and responses from their colleagues, top management or even their clients. For example, several studies have been conducted in investigating the impact of technology in carrying out tasks recognizing that technology does indeed improve service efficiency, increase productivity and improve company performance which has a direct impact on employee performance (Di Pietro, Pantano, \& Di Virgilio, 2014). 


\section{Understanding WhatsApp}

Whatsapp is a social media chat application that can be used on smartphones and is almost similar to BlackBerry Messenger. Whatsapp social media is an instant messaging application that functions to send and receive messages, without being charged pulses such as SMS and cell phones. This is because WhatsApp uses the same internet data package as other applications. (in Andjani, et all, 2018) The internet data network needed to run the whatsapp application is a $3 \mathrm{G}$ or $\mathrm{WiFi}$ connection. Features that can be used on whatsapp are, do personal / group chat on time (timelines) and cost effectiveness (cost effectivity)

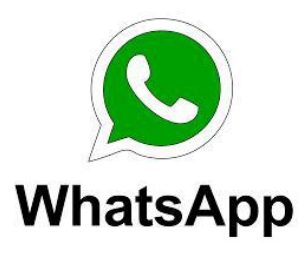

\section{Whatsap Feature}

Whatsapp has several features, including the following: 1 . Send a text message 2 . Receive and send photos from the camera directly or album 3. Sending video 4. Exchange documents both documents in the form of files and others 5. Make telephone and video calls or send voice recordings directly. 6. Share location using GPS 7. Send contact cards 8. Exchange emoticons and stickers through private chats or group chats. 9. Can change profile photos, post status, reserve messages, change numbers and maintain account security and manage privacy in using whatsapp in the settings feature (Andjani, et all, 2018)\

\section{Whatsapp Advantages}

Andjani, et all, (2018) mentioned some of the advantages of Whatsapp are: 1. There is no need for money to install the WhatsApp application on a smart phone and the cost is useless. 2. Can send messages, pictures, videos, audio and voice messages easily.3. Can chat with others with a quota of more than 70 people in one chat group. 4. Small data usage compared to other applications.

\section{Whatsapp Usage}

According to Nitisusastro (2012) explains there are several factors that can affect us in using a product, what is meant is whatsapp. These factors include: 1 . Knowledge Characteristics This knowledge includes everything about whatsapp, version, capabilities, how to download and use it, as well as the costs used to access it.2. BenefitsWe must know the benefits of whatsapp itself as what, advantages and disadvantages compared to other applications.3. Usage Use here is more time 
oriented, ie how long whatsapp can be used if connected to an internet connection and the purpose of using whatsapp.

\section{Expert Performance}

Performance comes from the word work performance which is one's work performance. Performance translates into performance, also means work performance, work performance, work performance or work results, work performance (Sedarmayanti, 2009 :) While according to Mangkunegara (2005) the notion of performance (performance work) is work quality and quantity achieved by an employee in carrying out his duties according to responsibilities in accordance with the responsibilities given to him. Furthermore Mangkunegara (2005), states that: "Employee performance (work performance) is the result of the quality and quantity of work achieved by an employee in carrying out their duties in accordance with the responsibilities given to him". Russell and Bernadin (1993) suggested that performance is a record

\section{Performance Measurement}

According to Umar Husein (2005) the elements assessed in performance are as follows: a. A. Quality of work, b. Honesty of employees.c. Initiative, d. Presence. e. Attitude. f. Cooperation. g. Reliability.h. Knowledge of work i. To be responsible j. Utilization of time

According to Davis and Newstorm (1996: 142) for organizations that are quite advanced the performance measurement results can be used as considerations for promotion, demotion, training, compensation, termination of employment and so on. The use of performance appraisal as a consideration of these things will motivate employees to always improve their performance, which in turn will also affect organizational performance. Seeing how important the results of performance appraisal are for organizations and employees, implementation needs to be carried out as objectively as possible, by avoiding likes and dislikes of evaluators

\section{METHODOLOGY}

The research approach used is quantitative descriptive. Descriptive qualitative research approach is a research approach that describes, illustrates and translates data and results of research analyzes in writing, systematic and structured. While the analytical method used is correlation analysis and ordinal logistic regression to see the correlation between the correlation between the value and the effect of perception variables on the ease of use of communication media, the perception of the use of communication media on the variable performance of expert members from the Indonesian Golkar Faction. While the manipulations in this study were all Golkar Faction Experts who were active in 2019 with a total of 455 TAA (91 DPR Members). The sampling technique used in this study is a 
stratified random sampling probability sampling technique because of population heterogeneity, with proportional strata. The sample in this study was taken using the Taro Yamane formula:

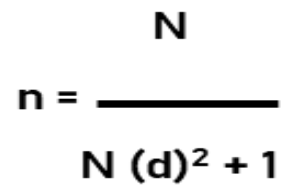

Information:

$\mathrm{n}=$ sample size.

$\mathrm{N}=$ Population ,.

$\mathrm{d}=$ level of precision.

Then the number of samples in this study were 213 experts from the Golkar Faction of the Republic of Indonesia DPR who were respondents. Research data collection is carried out through questionnaires or questionnaires that are used as research data collection instruments, with the following variables:

\section{Data Collection \& Operationalization Variables}

Research data collection is carried out through questionnaires or questionnaires used as research data collection instruments, with the following variables:

Table 1. Operationalization of Research Variables

\begin{tabular}{|c|c|}
\hline $\begin{array}{c}\text { Variable } \\
\text { (X1) }\end{array}$ & Perception of the Use of WhatsApp Communication Media \\
\hline Indicator & $\begin{array}{l}\text { - Speed up Work } \\
\text { - Increase the effectiveness of the task } \\
\text { - Getting the information needed } \\
\text { - Simplify work }\end{array}$ \\
\hline \multirow{2}{*}{\multicolumn{2}{|c|}{$\begin{array}{l}\text { - The use of WhatsApp can increase productivity in work organizations } \\
\text { - } \quad \text { WhatsApp helps me quickly provide work reports to my leaders or fellow TAA. } \\
\text { - } \text { Often I use wahtsapp to directly submit reports or information to the leadership. } \\
\text { - } \quad \text { Sometimes I often get information and work (ask questions, answer, discuss) through } \\
\text { - WhatsApp } \\
\text { - Information via WhatsApp is very easy and cost-effective. } \\
\text { - Often I get information through notifications. } \\
\text { - The message that I conveyed directly to the Anggo device } \\
\text { The use of WhatsApp accelerates the dissemination of information to all members of } \\
\text { the TAup faction }\end{array}$}} \\
\hline & \\
\hline $\begin{array}{c}\text { Variable } \\
(\mathrm{X} 2)\end{array}$ & Persepsi Kemudahan Penggunaan Media Komunikasi WhatsApp \\
\hline Indicator & $\begin{array}{ll}- & \text { Easy to understand and easily accessed } \\
- & \text { Operationalization is clear and easy to control }\end{array}$ \\
\hline
\end{tabular}




\section{- $\quad$ Message or news can be clear}

Operasionalisasi :

- The features in WhatsApp are familiar when you try it for the first time.

- I had no trouble when registering for the first time on WhatsApp.

- $\quad$ Easily upload / upload documents (photos, videos, articles, news, etc.).

- I easily find the information I want

- The use of WhatsApp is not restricted in use and is free to enter and exit the Group.

- Information disseminated is limited to registered Group members.

- I can easily access fota and documents, comments and comments or statements from all members of the WhatsApp group

- $\quad$ All group members can interact and get information.

- Has a variety of operating systems or the web (WhatsApp.web) that is easy to use

\begin{tabular}{cll}
\hline $\begin{array}{c}\text { Variable } \\
(\mathrm{Y})\end{array}$ & Performance of the Go \\
& - & Quality of work \\
& - & initiative \\
& - & attendance \\
Indicator & - & Cooperation \\
& - & Knowledge of work \\
& - & Responsible \\
& - & Time utilization
\end{tabular}

Operasionalisasi :
- $\quad$ I come to the office every day except holidays and confirm attendance via WhatsApp to fellow TAA / Leaders

- I understand instructions about work and assignments given to me via WhatsApp quickly and easily.

- Often get new knowledge / information about work through broadcats (dissemination) links on WhatsApp that help and facilitate completing work.

- I feel more responsible for the work given because the leader's message / order can be conveyed directly to me.

- The information provided via WhatsApp is always accurate and satisfies my boss because it can be confirmed directly to the source online quickly and easily

- I always do my work on time because it is monitored directly (online) by the leadership

- I am actively involved in every discussion and communication on the respective TAA WhatsApp group / commission.

- $\quad$ Often the joint task completion initiative starts with creating a WhatsApp group working together for information and communication media.

\section{Analysis Techniques}

Data analysis was performed using correlation analysis techniques and ordinal logistic regression analysis techniques. Correlation analysis technique is used to determine the correlative level (significance) of the indicators of each dependent variable (X1 and $\mathrm{X} 2$ ) to the independent variable (Y). In addition, ordinal logistic regression analysis is used because the dependent variables (X1 and X2) are multilevel scale scale data. 


\section{RESULTS AND DISCUSSION}

In discussing the results of research and discussion on the influence of the Use of WhatsApp Communication Media Perception by Members of the Indonesian Parliament Members in the Golkar Faction referring to the theory put forward by Davis, Technology Acceptance Model (Davis 1989) where TAM suggests that the perceived usefulness and ease of perceived use determine individual's intention to use a system with a view to using serving as a mediator of actual system usage. The perceived usefulness is also seen as directly affected by the perceived ease of use. The underlying link between the two main constructs and user attitudes, intentions and behavior of actual technology use, is determined using the theoretical foundation of TRA. Attitudes and benefits felt together determine behavioral intentions and attitudes are determined by perceived benefits and perceived ease of use. The following reviews describe the research results. Furthermore, for performance measurement refers to the opinion of Umar Husei (2005) which consists of work quality, employee honesty, initiative, attendance, attitude, cooperation, reliability, knowledge of work, responsibility, time utilization

Perceptions about the use of WhatsApp communication media by experts in the Indonesian Parliament Golkar Faction focused on the level of expert judgment on the benefits obtained after using communication media in carrying out their main duties and functions, as shown in the table:

\begin{tabular}{|c|c|c|c|c|}
\hline Sample 1 & Sample 2 & Correlation & $95 \%$ CI for $p$ & P-Value \\
\hline$\times 1.3$ & $\times 1.2$ & 0.548 & $(0,447 ; 0.634)$ & 0.000 \\
\hline$\times 1.4$ & $\times 1.2$ & 0.584 & $(0,489 ; 0.666)$ & 0.000 \\
\hline$\times 1.5$ & $\times 1.4$ & 0.553 & $(0.453 ; 0.639)$ & 0.000 \\
\hline$\times 1.6$ & $\times 1.4$ & 0.546 & $(0.446 ; 0.633)$ & 0.000 \\
\hline$\times 1.8$ & $\times 1.4$ & 0.597 & $(0.504 ; 0.676)$ & 0.000 \\
\hline$\times 1.9$ & $\times 1.4$ & 0.544 & $(0,443 ; 0.631)$ & 0.000 \\
\hline$\times 1.9$ & $\times 1.6$ & 0.524 & $(0.421 ; 0.614)$ & 0.000 \\
\hline$\times 1.8$ & $\times 1.7$ & 0.508 & $(0,402 ; 0,600)$ & 0.000 \\
\hline
\end{tabular}

(Sumber: Hasil Analisis Penulis, 2019)

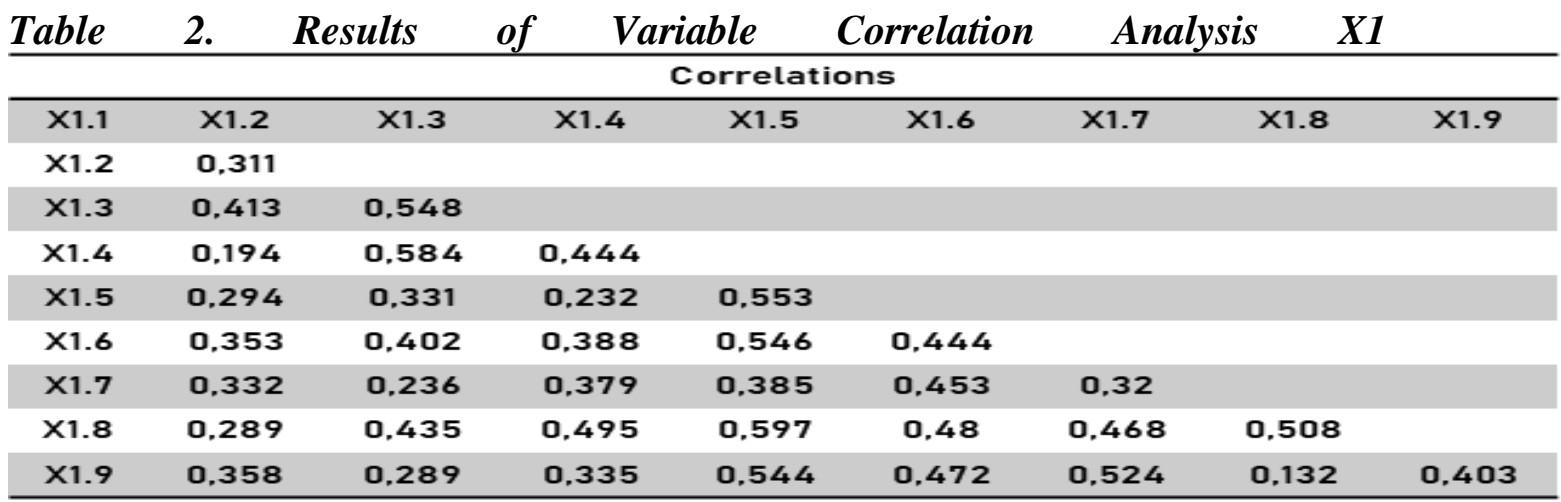




\begin{tabular}{|c|c|c|c|c|}
\hline Sample 1 & Sample 2 & Correlation & $95 \% \mathrm{Cl}$ for $\mathrm{p}$ & P-Value \\
\hline $\mathrm{X} 1.3$ & $\mathrm{X} 1.2$ & 0,548 & $(0,447 ; 0,634)$ & 0,000 \\
\hline $\mathrm{X} 1.4$ & $\mathrm{X} 1.2$ & 0,584 & $(0,489 ; 0,666)$ & 0,000 \\
\hline$\times 1.5$ & $\mathrm{X} 1.4$ & 0,553 & $(0,453 ; 0,639)$ & 0,000 \\
\hline $\mathrm{X} 1.6$ & $\mathrm{X} 1.4$ & 0,546 & $(0,446 ; 0,633)$ & 0,000 \\
\hline $\mathrm{X} 1.8$ & $\mathrm{X} 1.4$ & 0,597 & $(0,504 ; 0,676)$ & 0,000 \\
\hline $\mathrm{X} 1.9$ & $\mathrm{X} 1.4$ & 0,544 & $(0,443 ; 0,631)$ & 0,000 \\
\hline $\mathrm{X} 1.9$ & $\mathrm{X} 1.6$ & 0,524 & $(0,421 ; 0,614)$ & 0,000 \\
\hline$X 1.8$ & $\times 1.7$ & 0,508 & $(0,402 ; 0,600)$ & 0,000 \\
\hline
\end{tabular}

(Sumber: Hasil Analisis Penulis, 2019)

The use of WhatsApp communication media according to the Experts of Members of the Republic of Indonesia Parliament Golkar Faction has benefits in supporting performance, for several reasons, namely:

1. Messages delivered by Experts through WhatsApp communication media can be directly to the members of the Republic of Indonesia DPR Golkar faction quickly, this is used by experts to directly submit reports or information to leaders / members of the DPR RI in accordance with their main duties and functions, as well as other member needs.

2. Data and information obtained through the WhatsApp Group Experts Members of the Indonesian Parliament Golkar Faction are often obtained through notifications (notifications) very helpful to experts to keep abreast of developments in issues, discussions and discourses that develop and are warmly discussed. The data and information by experts can be used as a reference for compiling reports, case studies, or presentation material on each agenda of meetings and hearings, or other information that is of public concern that must be responded by members of the Indonesian Parliament Golkar Faction in accordance with its function as a legislative body. WhatsApp Media Group Experts Members of the Republic of Indonesia Golkar faction are also a means of exchanging information among fellow Golkar Faction experts.

3. The use of WhatsApp communication media by Experts Members of the Indonesian Parliament of the Golkar Faction is considered to be very efficient and cost-effective. The efficient use of WhatsApp media is supported by the internet network in the Republic of Indonesia DPR Building area which is the main internet service area. Therefore, the constraints of internet card-based prepaid or post-paid quota limitations are not felt by experts in carrying out their duties.

Perception Analysis of the Ease of Use of WhatsApp Communication Media by Experts Members of the Indonesian Parliament Golkar Faction

Perceived ease of use of WhatsApp communication media by experts in the DPR RI Golkar faction focused on the level of expert assessment of the benefits 
obtained after using communication media in carrying out their main duties and functions, as shown in the table:

Table 3. Results of Variable Correlation Analysis X2

\begin{tabular}{lcccccccc}
\hline & \multicolumn{7}{c}{ Correlations } \\
\hline$\times 2.1$ & $\times 2.2$ & $\times 2.3$ & $\times 2.4$ & $\times 2.5$ & $\times 2.6$ & $\times 2.7$ & $\times 2.8$ & $\times 2.9$ \\
$\times 2.2$ & 0.556 & & & & & & \\
$\times 2.3$ & 0.428 & 0.557 & & & & & \\
$\times 2.4$ & 0.344 & 0.315 & 0.333 & & & & \\
$\times 2.5$ & 0.45 & 0.393 & 0.449 & 0.297 & & & \\
$\times 2.6$ & 0.454 & 0.449 & 0.339 & 0.405 & 0.485 & & \\
$\times 2.7$ & 0.481 & 0.4 & 0.559 & 0.391 & 0.424 & 0.576 & \\
$\times 2.8$ & 0.496 & 0.527 & 0.632 & 0.397 & 0.437 & 0.526 & 0.699 & \\
$\times 2.9$ & 0.429 & 0.421 & 0.462 & 0.476 & 0.385 & 0.389 & 0.289 & 0.427 \\
\hline
\end{tabular}

\begin{tabular}{ccccc}
\hline Sample 1 & Sample 2 & Correlation & $95 \%$ CI for p & P-Value \\
\hline$\times 2.2$ & $\times 2.1$ & 0.556 & $(0,457 ; 0.641)$ & 0.000 \\
$\times 2.3$ & $\times 2.2$ & 0.557 & $(0,458 ; 0,642)$ & 0,000 \\
$\times 2.8$ & $\times 2.2$ & 0.527 & $(0,424 ; 0.617)$ & 0.000 \\
$\times 2.7$ & $\times 2.3$ & 0.559 & $(0,461 ; 0,644)$ & 0,000 \\
$\times 2.8$ & $\times 2.3$ & 0.632 & $(0,545 ; 0.706)$ & 0,000 \\
$\times 2.7$ & $\times 2.6$ & 0.576 & $(0,480 ; 0,658)$ & 0,000 \\
$\times 2.8$ & $\times 2.6$ & 0.526 & $(0,422 ; 0.616)$ & 0.000 \\
$\times 2.8$ & $\times 2.7$ & 0.699 & $(0,624 ; 0.761)$ & 0,000 \\
\hline
\end{tabular}

(Sumber: Hasil Analisis Penulis, 2019)

\begin{tabular}{|c|c|c|c|c|}
\hline \multicolumn{2}{|c|}{$\begin{array}{c}\text { Pairwise Pearson } \\
\text { Correlations }\end{array}$} & \multirow{2}{*}{$\begin{array}{c}\text { Nilai Korelasi } \\
0,699\end{array}$} & \multicolumn{2}{|c|}{ Tanggapan Responden } \\
\hline $\mathrm{X} 2.8$ & $\mathrm{X} 2.7$ & & $\begin{array}{l}\text { Semua anggota group bisa berinteraksi dan } \\
\text { mendapatkan informasi }\end{array}$ & $\begin{array}{l}\text { Saya mudah dalam mengakses foto, dokumen, } \\
\text { komentar atau peryataan dari semua anggota grup } \\
\text { WhatsApp }\end{array}$ \\
\hline $\mathrm{X} 2.8$ & $\mathrm{X} 2.3$ & 0,632 & $\begin{array}{l}\text { Semua anggota group bisa berinteraksi dan } \\
\text { mendapatkan informasi }\end{array}$ & $\begin{array}{l}\text { Mudah mengungah dokumen (foto,video, artikel, berita, } \\
\text { dil) }\end{array}$ \\
\hline $\mathrm{X} 2.7$ & $\mathrm{X} 2.6$ & 0,576 & $\begin{array}{l}\text { Saya mudah dalam mengakses foto, dokumen, } \\
\text { komentar atau peryataan dari semua anggota } \\
\text { grup WhatsApp }\end{array}$ & $\begin{array}{l}\text { Informasi yang disemapaikan hanya terbatas kepada } \\
\text { anggota Group yang telah terdaftar saja }\end{array}$ \\
\hline $\mathrm{X} 2.7$ & $\mathrm{X} 2.3$ & 0,559 & $\begin{array}{l}\text { Saya mudah dalam mengakses foto, dokumen, } \\
\text { komentar atau peryataan dari semua anggota } \\
\text { grup WhatsApp }\end{array}$ & $\begin{array}{l}\text { Mudah mengungah dokumen (foto,video, artikel, berita, } \\
\text { dil) }\end{array}$ \\
\hline $\mathrm{X} 2.3$ & $\mathrm{X} 2.2$ & 0.557 & $\begin{array}{l}\text { Mudah mengungah dokumen (foto,video, } \\
\text { artikel, berita, dll) }\end{array}$ & $\begin{array}{l}\text { Saya tidak mengalami kesulitan saat mendaftar } \\
\text { pertama kali pada Whats } A p p\end{array}$ \\
\hline $\mathrm{X} 2.2$ & $\mathrm{X} 2.1$ & 0,556 & $\begin{array}{l}\text { Saya tidak mengalami kesulitan saat } \\
\text { mendaftar pertama kali pada WhatsApp }\end{array}$ & $\begin{array}{l}\text { Fitur-fitur yang ada didalam WhatsApptidak asing saat } \\
\text { dicoba pertama kali }\end{array}$ \\
\hline $\mathrm{X} 2.8$ & $\mathrm{X} 2.2$ & 0,527 & $\begin{array}{l}\text { Semua anggota group bisa berinteraksi dan } \\
\text { mendapatkan informasi }\end{array}$ & $\begin{array}{l}\text { Saya tidak mengalami kesulitan saat mendaftar } \\
\text { pertama kali pada WhatsApp }\end{array}$ \\
\hline $\mathrm{X} 2.8$ & $\mathrm{X} 2.6$ & 0,526 & $\begin{array}{l}\text { Semua anggota group bisa berinteraksi dan } \\
\text { mendapatkan informasi }\end{array}$ & $\begin{array}{l}\text { Informasi yang disemapaikan hanya terbatas kepada } \\
\text { anggota Group yang telah terdaftar saja }\end{array}$ \\
\hline
\end{tabular}

Perceived ease of use of WhatsApp communication media by Experts Members of the Indonesian Parliament in the Golkar Faction in supporting performance, for several reasons, namely:

First, the ease of use of WhatsApp communication media begins at the time of the easy application installation process (user friendly) because it already has an understanding about the use of WhatsApp communication media, knowing the benefits and use of WhatsApp in communicating. Then, the ease of accessing data and information, providing comments and interacting from WhatsApp information 
media, as well as the ease of making various WhatsApp groups as needed. As well as other facilities obtained by experts in using WhatsApp communication media, these media features are very supportive for providing information or reporting in the form of news texts or documents in large numbers, photos and videos with a much greater capacity, quickly, massively and continue to be connected so that it is very easy to disseminate information to all Golkar Faction Experts internally, or to the work partners of members or factions. Other. WhatsApp Filtration consists of Whatsapp having several features, including the following: 1). Send text messages 2) Receive and send photos from live cameras or albums 3) Send videos 4) Exchange documents both in file and other forms 5) Make telephone and video calls or send voice recordings directly. 6) Share locations using GPS 7) Send contact cards 8) Exchange emoticons and stickers through private chats or group chats. 9). Can change profile photos, post status, reserve messages, change numbers and maintain account security and manage privacy in using whatsapp in the settings feature (Andjani 2018)

Perceived ease of use of WhatsApp communication media by Members of the Golkar Faction of the Indonesian Parliament in supporting performance, because the ease of use of WhatsApp communication media began during the process of installing user-friendly applications because it already had an understanding of using WhatsApp communication media, knowing the benefits and use of WhatsApp in communication. Then, having ease in accessing data and information, giving comments and interacting with WhatsApp information media, as well as creating various WhatsApp groups as needed and providing other facilities obtained by experts in using WhatsApp communication media is that this media feature is very supportive for providing information or reporting in the form of news texts or documents in large numbers, photos and videos with a much greater capacity, fast, massive and connected continuously so it is very easy to disseminate information to all Golkar Faction Experts internally, or to members or working partners of this faction in accordance with what was stated by Andjani (2018)

Analysis of the Influence of the Use of WhatsApp Communication Media on the Performance of Expert Members of the Golkar Faction

The measurement of the level of influence of the use of WhatsApp communication media on the improvement of the performance of Golkar Faction Experts was analyzed based on the logistic regression method to illustrate the relationship between the variables of perceived usefulness and perceived ease of use on performance improvement. This analysis is calculated by the following rules:

1. The value of variable $\mathrm{X} 1$ is the total value of the operational factors of variable $\mathrm{X} 1$.

2. The value of variable $\mathrm{X} 2$ is the total value of the operational factors of variable $\mathrm{X} 2$. 
3. The value of variable $\mathrm{Y}$ is the total value of the operational factors of variable $\mathrm{Y}$, with the results of the analysis as follows:

Table 4. Results of Ordinal Variable Logistic Regression Analysis

$$
\text { (X1, X2, against Y }
$$

\begin{tabular}{|c|c|c|c|c|c|c|c|}
\hline \multirow[b]{2}{*}{ Predictor } & \multirow[b]{2}{*}{ Coef } & \multirow[b]{2}{*}{ SECoef } & \multirow[b]{2}{*}{$\mathbf{z}$} & \multirow[b]{2}{*}{$\mathbf{P}$} & \multirow{2}{*}{$\begin{array}{l}\text { Odds } \\
\text { Ratio }\end{array}$} & \multicolumn{2}{|c|}{$95 \% \mathrm{Cl}$} \\
\hline & & & & & & Lower & Upper \\
\hline Const(1) & 12.4776 & 1.90152 & 6.56 & 0.000 & & & \\
\hline Const(2) & 12.7743 & 1.88341 & 6.78 & 0.000 & & & \\
\hline Const( 3 ) & 13.6318 & 1.85736 & 7.34 & 0.000 & & & \\
\hline Const (4) & 14.0281 & 1.85439 & 7.56 & 0.000 & & & \\
\hline Const(5) & 14.9542 & 1.86282 & 8.03 & 0.000 & & & \\
\hline Const (6) & 15.3363 & 1.87077 & 8.20 & 0.000 & & & \\
\hline Const (7) & 15.8495 & 1.88474 & 8.41 & 0.000 & & & \\
\hline Const ( 8 ) & 16.0161 & 1.88985 & 8.47 & 0.000 & & & \\
\hline Const (9) & 16.8175 & 1.91832 & 8.77 & 0.000 & & & \\
\hline Const(10) & 17.4846 & 1.94444 & 8.99 & 0.000 & & & \\
\hline Const(11) & 17.8811 & 1.96029 & 9.12 & 0.000 & & & \\
\hline Const(12) & 18.3119 & 1.97742 & 9.26 & 0.000 & & & \\
\hline Const(13) & 18.5764 & 1.98758 & 9.35 & 0.000 & & & \\
\hline Const (14) & 18.7936 & 1.99563 & 9.42 & 0.000 & & & \\
\hline Const(15) & 18.8708 & 1.99841 & 9.44 & 0.000 & & & \\
\hline Const(16) & 19.1032 & 2.00651 & 9.52 & 0.000 & & & \\
\hline Const(17) & 19.6228 & 2.02309 & 9.70 & 0.000 & & & \\
\hline Const (18) & 19.9203 & 2,03139 & 9.81 & 0.000 & & & \\
\hline$\times 1$ & -0.175356 & 0.0490062 & -3.58 & 0.000 & 0.84 & 0.76 & 0.92 \\
\hline$\times 2$ & -0.265822 & 0.0381360 & -6.97 & 0.000 & 0.77 & 0.71 & 0.83 \\
\hline Pairs & Number & Percent & \multicolumn{3}{|c|}{ Summary Measures } & \multicolumn{2}{|c|}{ Value } \\
\hline Concordant & 16082 & 74.0 & \multicolumn{3}{|c|}{ Somers'D } & \multicolumn{2}{|c|}{0.50} \\
\hline Discordant & 5173 & 23,8 & \multirow{3}{*}{\multicolumn{3}{|c|}{$\begin{array}{c}\text { Goodman-Kruskal Gamm } \\
\text { Kendall's Tau-a }\end{array}$}} & \multirow{2}{*}{\multicolumn{2}{|c|}{$\begin{array}{l}0.51 \\
0.46\end{array}$}} \\
\hline Ties & 479 & 2.2 & & & & & \\
\hline \multirow[t]{2}{*}{ Total } & 21734 & 100,0 & & & & \multicolumn{2}{|c|}{0.46} \\
\hline & & & & & Odds & \multicolumn{2}{|c|}{$95 \% \mathrm{Cl}$} \\
\hline Predictor & Coef & SECoef & z & $\mathbf{P}$ & Ratio & Lower & Upper \\
\hline Const(1) & 12,4776 & 1.90152 & 6.56 & 0.000 & & & \\
\hline Const(2) & 12.7743 & 1.88341 & 6.78 & 0.000 & & & \\
\hline Const (3) & 13.6318 & 1.85736 & 7.34 & 0.000 & & & \\
\hline Const (4) & 14.0281 & 1.85439 & 7.56 & 0.000 & & & \\
\hline Const(5) & 14.9542 & 1.86282 & 8.03 & 0.000 & & & \\
\hline Const (6) & 15.3363 & 1.87077 & 8.20 & 0.000 & & & \\
\hline Const (7) & 15.8495 & 1.88474 & 8.41 & 0.000 & & & \\
\hline Const (8) & 16.0161 & 1.88985 & 8.47 & 0.000 & & & \\
\hline Const (9) & 16.8175 & 1.91832 & 8.77 & 0.000 & & & \\
\hline Const(10) & 17.4846 & 1.94444 & 8.99 & 0.000 & & & \\
\hline Const(11) & 17.8811 & 1.96029 & 9.12 & 0.000 & & & \\
\hline Const(12) & 18.3119 & 1.97742 & 9.26 & 0.000 & & & \\
\hline Const(13) & 18.5764 & 1.98758 & 9.35 & 0.000 & & & \\
\hline Const (14) & 18.7936 & 1.99563 & 9.42 & 0.000 & & & \\
\hline Const(15) & 18.8708 & 1.99841 & 9.44 & 0.000 & & & \\
\hline Const(16) & 19.1032 & 2.00651 & 9.52 & 0.000 & & & \\
\hline Const(17) & 19.6228 & 2.02309 & 9.70 & 0.000 & & & \\
\hline Const(18) & 19.9203 & 2,03139 & 9.81 & 0.000 & & & \\
\hline$\times 1$ & -0.175356 & 0.0490062 & -3.58 & 0.000 & 0.84 & 0.76 & 0.92 \\
\hline$\times 2$ & -0.265822 & 0.0381360 & -6.97 & 0.000 & 0.77 & 0.71 & 0.83 \\
\hline
\end{tabular}




\begin{tabular}{ccccc}
\hline Pairs & Number & Percent & SummaryMeasures & Value \\
\hline Concordant & 16082 & 74.0 & Somers'D & 0.50 \\
Discordant & 5173 & 23.8 & Goodman-Kruskal Gamma & 0.51 \\
Ties & 479 & 2.2 & Kendall's Tau-a & 0.46 \\
Total & 21734 & 100.0 & & \\
\hline
\end{tabular}

Table 4 shows the value of the results of the regression analysis of the influence of the use of WhatsApp communication media on the improvement of the performance of experts from the Golkar faction of the House of Representatives of the Republic of Indonesia, which is shown with a Concordant (Percent) value of $74.0 \%$. So it can be said that the value of the influence of the use of WhatsApp communication media on improving the performance of Experts of the Members of the Indonesian Parliament of the Golkar Faction is 74\%.

Furthermore, the use of WhatsApp communication media by expert members of the Indonesian Parliament of the Golkar Faction must certainly be accompanied by improved performance. The following are the assessment of the factors that have led to an increase in the performance of experts from the Republic of Indonesia DPR Golkar faction after using WhatsApp, among others, as follows: Table 4 shows the value of the results of the regression analysis of the influence of the use of WhatsApp communication media on the improvement of the performance of experts from the Golkar faction of the House of Representatives of the Republic of Indonesia, which is shown with a Concordant (Percent) value of $74.0 \%$. So it can be said that the value of the influence of the use of WhatsApp communication media on improving the performance of Experts of the Members of the Indonesian Parliament of the Golkar Faction is $74 \%$.

The use of WhatsApp communication media gets an average result of 3.9 which is categorized high, with this high category meaning that respondents have felt the influence of using WhatsApp communication media in carrying out their main tasks, functions and responsibilities. In order to support the duties of Members of the Indonesian Parliament in carrying out their duties, the use of WhatsApp as a communication medium is seen as a support system that supports the implementation of the tasks of experts, both technically and administratively. This is consistent with the results of research conducted by Andjani, et al (2018) and Mega Ulva Sari Sihombing (2017), which shows that the use of whatsApp can influence employee performance

The use of WhatsApp communication media encourages quality improvement and performance quantity in accordance with the responsibilities that are given to it. The use of WhatsApp communication media can directly increase the performance of experts in terms of improving the quality of work, increasing initiative in completing work, maximizing attendance, increasing responsibility for work, forming cooperation among experts, and optimizing the use of time effectively and efficiently in the completion of work. 


\section{CONCLUSION}

The results of research that have been analyzed previously can be drawn several conclusions including:

1. The use of WhatsApp communication media by Golkar faction experts in the House of Representatives is felt to be very easy, effective, efficient at a low cost because messages delivered by Experts through WhatsApp communication media can be directly to the devices of the DPR RI Golkar Faction member quickly, this is utilized by experts to directly submit reports or information to the leadership / members of the DPR RI in accordance with their main duties and functions, as well as the needs of other members of the Golkar faction of the DPR RI.

2. Data and information obtained through the WhatsApp Group Experts Members of the Indonesian Parliament Golkar Faction are very helpful to experts to keep abreast of developments in issues, discussions and discourses that develop and are warmly discussed. The data and information can be used by the experts as a reference for compiling reports, case studies, or presentation materials on each agenda of meetings and hearings, or other information that is of public concern that must be responded to by members of the Indonesian Parliament Golkar Faction.

3. Ease of use of WhatsApp communication media starts during the application installation process with user friendly features because the majority of experts already have instructions on using WhatsApp communication media, knowing the benefits and use of WhatsApp in communicating.

4. The ease of accessing data and information, providing comments and interacting from WhatsApp information media, as well as the ease in creating various WhatsApp Groups according to needs is very helpful in carrying out the main tasks and functions of experts.

5. The influence of the use of WhatsApp communication media on the improvement of the performance of experts from the Golkar faction of the House of Representatives of the Republic of Indonesia is very significant (74.0\%), with a high level of assessment (an average of 3.9) which means that the experts really feel the benefits of the influence of using the WhatsApp communication media towards performance improvement in carrying out the main tasks, functions and responsibilities.

\section{Suggestion}

From the results of the research and conclusions, some suggestions can be submitted as follows:

1. To further improve the performance of expert members of the DPR-RI, it must be done by increasing its participation such as intensifying experts at commission and coordination meetings at the commission and reducing the work of experts in matters outside the office, especially those not related to their main tasks and functions. DPR-RI member experts.

2. To increase the Expert Staff members get their respective duties, then from the division of tasks must be explained to each expert the limits of the tasks that 
have been and will be done so that when working on the task does not overlap the task authority between the one employee and the Expert the other.

3. This study has limitations in the selection of variables to measure performance improvement in relation to the use of WhatsApp communication media. Because it is intuitive, the authors suggest for further research to include variables as extrinsic factors of the influence of the external environment on improving performance to further complement the analysis of this study.

\section{REFFERENCES}

\section{Book}

Arifin HF. 2015. The Effect of Whatsapp on Students' Closed Behavior (Survey on Communication Studies Students of FISIKOM, Sunan Kalijaga State Islamic University, Yogyakarta Force, 2014). Yogyakarta: Social Sciences and Humanities UIN Sunan Kalijaga Yogjakarta

Arnold, Hugh J., and Danield C. Feldman. 1986. Individual in Organizations. New York: McGraw Hill, Series in Management.

Davis, Fred D. (1989). Perceived Usefulness, Perceived Ease of Use, and User Acceptance of Information Technology. MIS Quarterly, 13 (3), 319-340.

Estaswara. 2008. Think IMC, The Effectiveness of Communication to Increase Corporate Brands and Profit, Jakarta: PT Gramedia Pustaka Utama Husein Umar. 2005. Company Performance Evaluation. Jakarta: Gramedia Main Library.

Jankowski, Nicholas. 2002. Community Media in the Information Age:

Perspectives and Prospects. Cresskill, NJ: Hampton Press.

Kaplan, Andreas M., \& Michael Haenlein. 2010. Users Of The World, Unite! The Challenges And Opportunities Of Social Media. Business Horizons, Vol. 53 No. 1

Kim, B. G., Park, S. C., \& Lee, K. J. 2007. "A Structural Equation Modeling of the Internet Acceptance in Korea" Electronic Commerce Research and Applications, 6 (4), 425-432

Kriyantono, Rachmat. 2006. Practical Communication Research Techniques,

Jakarta: Prenada Media Group

Kusriyanto, Bambang. 1993. Increasing Employee Productivity. Jakarta: LPM.

Mangkunegara, Anwar Prabu. 2005. Human Resources company. Teenager.

Rosdakarya: Bandung

Miller, K. 2011. Organizational Communication: Approaches And Processes

Boston: Wadsworth.

Moriarty, Sandra, Nancy Mitchell, and Willian Wells. 2011. Advertising

(Prinsiples \& Practice) 8th edition, translation, Jakarta Kencana.

Morissan. 2010. Advertising: Integrated Marketing Communication, Jakarta

: Kencana Prenada Media Group

Mulyana, Deddy. 2007. An Introduction to Communication Studies. Bandung: PT 
Remaja Rosdakarya

Nasrullah, Rulli. 2015. Social Media Perspective on Communication, Culture, and Sociotechnology. Bandung: Simbiosa Rekatama Media

Nitisusastro M. 2012. Consumer Behavior. Bandung (ID): Alfabeta

Pace, R. W., \& Faules, D. F. 1994. Organizational communication. Englewood Cliffs, N.J: Prentice Hall. Chicago

Poster, Mark. 1998. The Second Media Age (Boudrillard "The desire of simulation) "... Cambridge: Polity Press.

Rahkmat, Jalaluddin. 2008. Psychology of Communication. Bandung: PT Remaja Rosdakarya

Safko, Lon. 2012. The Social Media Bible: Tactics, Tools \& Strategies for Business Success. New Jersey: John Wiley \& Sons, Inc

Salim, Agus (ed). 2001. The Theories and Paradigms of Social Research from Denzin Guba and their Applications. Yogyakarta: Tiara Wacana.

Awarayanti.2009. Human Resources and Work Productivity. Bandung: CV Forward Mandar.

Shannon, Claude E. \& Warren Weaver (1949): A Mathematical Model of Communication Urbana, IL :. University of Illinois Press.

Sugiyono 2012. Quantitative, Qualitative, R\&D Research Methods. 15th print Bandung: Alfabeta

West, Richard and Lynn H. Turner. 2009. Introducing Communication Theory: Analysis and Application, 3rd ed. Jakarta: Salemba Humanika.

Wiryanto. 2004. Introduction to Communication Studies. Jakarta: PT Grasindo Journal of Agents Affecting on Employees Retention in Banking Sector: An Investigation from Karachi

\section{Journal}

Nawaz Ahmad * Assistant Professor at Indus University, Karachi, Pakistan nawazahmad_pk@hotmail.com

Faiq Matin MS student at Indus University, Karachi, Pakistan faiqmatin@yahoo.com

Factors Affecting on Employees Retention in Banking Sector: An Investigation from Karachi

A Andjani1a, IA Ratnamulyani2, AA Kusumadinata3a, 2018. The Use of Whatsapp Communication Media Against the Effectiveness of Employee Performance. Journal of Communication Volume 4 Number 1, April 2018

Lee, J., Peng, Y., Lin, W.Y., Parrish, J.Z. (2015). Coordinate control of dendrite patterning and dynamics terminals by the membrane protein Raw. Development 142 (1): 162--173.

Nic Newman with Richard Fletcher \& Nielsen, 2018). Loredana Di Pietro, Eleonora Pantano, Francesca Di Virgilio, 20 Frontline Employees ' Attitudes Towards Self-Service Technologies: Threats Or Opportunity For Job Performance? Journal of Retailing and Consumer Services Volume 21, Issue 5, September 2014, Pages 844-850

Newman, Nic, Richard Fletcher, \& Nielsen, 2018. Top Social Media and 
Messaging Platforms, https://www.researchgate.net/figure/Top-Social-Med ook

\section{Internet}

Indonesian Internet Service Users Association. 2014. Indonesian Internet User Profile 2014, APJII Survey with Puskakom UI, pdf documents accessed via https://apjii.or.id/downfile/file/PROFILPENGGUNAINTERNETINDONE SIA2014.pdf

The 2015 Ministry of Technology and Higher Education Research Annual Report, pdf document, accessed through http://www.ristekdikti.go.id/wpcontent/uploads/2016/07/ANNUAL-REPORT-2015-VERSI-LOW-RESS. pdf

http://www.internetworldstats.com/stats3.htm

http://www.pikiran-rakyat.com/luar-negeri/2017

http://isparmo.web.id/2016/11/21/data-statistik-pengguna-internet-indonesia2016).

Mayfield, Antony. 2008. What is Social Media ?. London: Icrossing. E-Book. Downloaded via

http://www.icrossing.com/uk/sites/default/files_uk/insight_pdf_files/What\%20is \%20Social\%20Media_iCrossing_ebook.pdf

Prensky, Marc. 2001. Digital Natives, Digital Immigrants, pdf documents downloaded via

http://marcprensky.com/writing/Prensky2020Digital20Natives,20Digital20Immigr ants20-20Part1.pdf 